\title{
The Integrative Conflict Mapping: A Strategic Instrument Towards Conflict Responsive Area
}

\author{
Suparman Abdullah ${ }^{1}$, Suryanto ${ }^{2}$, Hariashari Rahim ${ }^{3}$ * \\ ${ }^{1}$ Dosen Sosiologi Fisip Universitas Hasanuddin, Makassar, Indonesia, email: mansosio87@yahoo.com \\ ${ }^{2}$ Dosen Sosiologi Fisip Universitas Hasanuddin, Makassar, Indonesia, email: suryanto.sosiologiunhas@gmail.com \\ ${ }^{3}$ Dosen Sosiologi Fisip Universitas Hasanuddin, Makassar, Indonesia, email: ashariarrahim@gmail.com
}

\section{A R T I C L E I N F O}

\section{How to Cite:}

Abdullah, S., Simmau, S., Suryanto, \& Rahim, H. (2019). The Integrative Conflict Mapping: A Strategic Instrument Towards Conflict Responsive Area. Hasanuddin Journal of Sociology (HJS), $1(1), 56-65$.

Keywords: Integrative Conflict Mapping, Strategic Instrument, Conflict Potentials, Locality, Conflict Responsive Area

\begin{abstract}
A B S T R A C T
The most important of this study is to form an integrative instrument of conflict mapping towards conflict responsive area. It is the main benefit of the objectives of study that to gain a brief description of conflict potentials in local area and to propose a strategic model of local conflict responsive based on social capital. The method use is mixed method: quantitativequalitative. Data collected by questioner and in-depth interview during May to June 2016. The results of the study are; the strategic instrument towards conflict responsive area is integrative conflict mapping between conflict analysis and social capital potentials; there are 122 conflict potentials along May 2013 to May 2016, and the major conflict potential is natural and environmental resources issue. The second is economic resources. Ethnic and religion, then politics and territory is the next conflict potentials. This study proofs that conflict potentials could be prevent, manage and find resolution by profiling data through the implementation of integrative conflict mapping.
\end{abstract}

(C) 2019 Hasanuddin Journal of Sociology. All rights reserved

\section{INTRODUCTION}

Multi-ethnic, multi-cultural and multi-religion country, such as Indonesia is quite susceptible of social conflict. This is because of the perceived divergence of interest (Pruitt and Rubin, 2009). Based on National System of Violence Monitoring (SNPK) annual report of Coordinator Ministry of Human and Culture of Indonesia (2014), the major violence in Indonesia are 1.727 cases, conflict violence are 581 cases, household violence are 442 cases and justice enforcement are 193 cases. The conflict 
categorized into; resources conflict, governance conflict, political election conflict, identity conflict, separatism, etc. There are 7.335 violence, average, happened in a day. The resource conflict caused 133 death, average, in three days, whereas, identity conflict has killed 83 people.

In this point of view, SNPK defined conflict as the event causes violence. The related point, The Social Ministry of Indonesia (2013) in regulation number 7/2012 about social conflict determines that social conflict is the contradiction or physical fight (riot) with violence between two or more social groups in a range of time that impact social order largely and disturb the national security, and therefore, development is disturbed.

Based on the fact that Indonesian society potentially is involved into conflict, therefore, it is urgently to provide a conflict profile in each of provincials and regencies area. Here is the importance of this study. It aims to form an integrative instrument of conflict mapping towards conflict responsive area. The other one is to gain a brief description of conflict potentials in local area and to propose a strategic model of local conflict responsive based on social capital. Thus, at least, there must be three steps in the implementation of this study, they are; providing an integrative instrument for conflict potentials mapping, profiling conflict, and third is to propose a conflict prevention, management and solution based on local potentials that called local social capital.

\section{METHOD}

The method used in this study is mixed method (quantitative-qualitative). The study conducted in Gowa, Takalar, Bantaeng, Sinjai and Selayar Regency, South Sulawesi Province, Indonesia, on May to June 2014. There are 50 respondents as the sample of study. Respondents are those whom called stakeholders. They are traditional local leader, community leader, religion leader, social workers, civil society (NGO), women leader, youth organization leader, police leader, military leader, and conflict actors. It purposively selected 10 respondents in each regency. The data collected by questioner and indepth interview. Data analyzed by using statistical analysis and qualitative analysis.

\section{RESULTS}

\subsection{Integrative Conflict Potentials Mapping (ICPM)}

What is integrative conflict mapping, actually? It is necessary to describe about integrative and conflict mapping. In this case, integrative refers to integrative paradigm (Ritzer, 2004). It is not enough to use a single paradigm to study sociological issues. We need multi perspectives to determine and have a clear understanding toward social phenomena. It may macro-micro or micro-macro or micro-micro or macro-macro point of view. 
Conflict mapping is a very urgent action to do before intervene conflict management and conflict resolution. We need a brief description about multi dimensions of conflict potential, the cause of conflict, the actors of conflict, social and politics response, cultural history and background of society whom conflicting. Therefore, conflict mapping is an urgent tool to describe all of aspects of conflict, include, the actors of conflict perspective toward conflict. They may be sharing experience and each point of view about conflict (Susan, 2009).

Related to conflict mapping, therefore, we need integrative approach, either. In this case, before conducting the study it is necessary to decide a strategic instrument both in explanation of conflict potentials profile and the local knowledge and experience in order to prevent, manage or finding conflict resolution. It is quite difficult to prevent, manage and even determining conflict resolution without a brief information and potentials capital that local community have.

It is necessary to proposes the integrative perspective on conflict mapping. In this case, The Conflict Sensitivity Consortium (CSC, 2012) helps indeed to present a clear conflict analysis. CSC argued a systematic approach to understanding the background and history of the conflict, identifying all the relevant groups involved, understanding the perspectives of these groups and how they relate to each other, and identifying the causes of conflict. They, then, describe those components to analyzed by breaking down into four elements of conflict data base to describe with bounded questions. Those elements are profile of conflict, conflict causes, conflict actors, and conflict dynamics.

The conflict itself has a different character in each multicultural society, such South Sulawesi Province, Indonesia. There are many different interests, different ethnic, tribe, language, religion, and culture. It is really colorful society here. On the other hand, those differences have multi potentials too. The local people, in each group of society, have they own wisdom to survive in the chaos situation. Therefore, Ife (2008) belief that the respect to locality is the right way to change the paradigm of development. The globalization, Ife said, forms the 'top-down' development. It is really a kind of colonialism development. This perspective ought to be changed into 'button-up development'. It is the manifestation of locality appreciation and responsive.

In hand to hand connection to locality, it is important to remember the social capital concepts of many experts, such as, Bourdieu, Putnam, Fukuyama, etc. But in this explanation, it is important to note Lin (2004) that social capital defines investment of resources with expected returns in the marketplace. The meaning is that social capital captured through social relations. Here, capital is seen as a social asset by virtue of actors' connections and access to resources in the network or group of which they are members. Therefore, social capital is investment in social relations with expected returns in the 
marketplace.

Connected to the point, Abdullah (2016) determine six elements of social capital based on World Bank. They are; group and networking, belief and solidarity, collective action and partnership, information and communication, social inclusion and cohesion, and Empowerment and political action.

Furthermore, the four elements of conflict analysis integrate with six elements of social capital. That is the integrative conflict mapping instrument that we call 'The Integrative Conflict Mapping Matrix'. It really an integrative instrument to profile conflict potentials and the potential of conflict prevention, conflict management and conflict resolution. For clear description look at the following matrix.

Matrix of Integrative Conflict Mapping

\begin{tabular}{|c|c|c|c|c|}
\hline \multicolumn{4}{|c|}{ Conflict Profile } & \multirow{2}{*}{$\begin{array}{c}\text { Social Capital } \\
\text { Potentials to } \\
\text { End Conflict }\end{array}$} \\
\hline Profile of Conflict & $\begin{array}{c}\text { Conflict } \\
\text { Causes } \\
\end{array}$ & $\begin{array}{l}\text { Conflict } \\
\text { Actors }\end{array}$ & $\begin{array}{c}\text { Conflict } \\
\text { Dynamics }\end{array}$ & \\
\hline $\begin{array}{l}\text { 1. What is the } \\
\text { political, } \\
\text { economic, and } \\
\text { socio-cultural } \\
\text { context? }\end{array}$ & $\begin{array}{l}\text { 1. What are } \\
\text { structural } \\
\text { causes of } \\
\text { conflict? }\end{array}$ & $\begin{array}{l}\text { 1. Who are } \\
\text { the main } \\
\text { actors? }\end{array}$ & $\begin{array}{l}\text { 1. What are the } \\
\text { current } \\
\text { conflict } \\
\text { trends? }\end{array}$ & $\begin{array}{l}\text { 1. Group and } \\
\text { networking }\end{array}$ \\
\hline Answers: & Answers: & Answers: & Answers: & Answers: \\
\hline$\ldots \ldots \ldots \ldots+\cdots$ & $\ldots+\cdots \cdots \cdots+\cdots$ & $\ldots \ldots \ldots+\ldots, \cdots$ & $\ldots \ldots \ldots+\ldots, \ldots$ & $\ldots \ldots+\ldots, \ldots, \ldots$ \\
\hline $\begin{array}{l}\text { 2. What are the } \\
\text { emergent } \\
\text { political, } \\
\text { economic, } \\
\text { ecological and } \\
\text { social issues? }\end{array}$ & $\begin{array}{l}\text { 2. What issues } \\
\text { can be } \\
\text { considered } \\
\text { as } \\
\text { proximate } \\
\text { causes of } \\
\text { conflict? }\end{array}$ & $\begin{array}{l}\text { 2. What are } \\
\text { their main } \\
\text { interest, } \\
\text { goals, } \\
\text { positions, } \\
\text { capacities, } \\
\text { and } \\
\text { relationshi } \\
\text { ps? }\end{array}$ & $\begin{array}{l}\text { 2. What } \\
\text { are } \\
\text { window } \\
\text { s of } \\
\text { opportu } \\
\text { nity }\end{array}$ & $\begin{array}{l}\text { 2. Belief and } \\
\text { solidarity }\end{array}$ \\
\hline Answers: & Answers: & Answers: & Answers: & Answers: \\
\hline$\cdots \cdots \cdots \cdots \cdots$ & $\cdots \cdots \cdots \cdots$ & $\ldots \ldots \ldots+\cdots \cdots$ & $\ldots \ldots \ldots+\cdots \cdots$ & $\ldots \ldots \ldots+\cdots, \ldots$ \\
\hline $\begin{array}{l}\text { 3. What specific } \\
\text { conflict } \\
\text { prone/affected } \\
\text { areas can be } \\
\text { situated within } \\
\text { this context? }\end{array}$ & $\begin{array}{l}\text { 3. What } \\
\text { triggers } \\
\text { can } \\
\text { contribute } \\
\text { to the } \\
\text { outbreak/f } \\
\text { urther } \\
\text { escalation } \\
\text { of } \\
\text { conflict? }\end{array}$ & $\begin{array}{l}\text { 3. What } \\
\text { institutio } \\
\text { nal } \\
\text { capacitie } \\
\text { s for } \\
\text { peace } \\
\text { can be } \\
\text { identified } \\
?\end{array}$ & $\begin{array}{l}\text { 3. What } \\
\text { scenario } \\
\text { s can be } \\
\text { develop } \\
\text { ed from } \\
\text { the } \\
\text { analysis } \\
\text { of the } \\
\text { conflict } \\
\text { profile, }\end{array}$ & $\begin{array}{l}\text { 3. Collective } \\
\text { action and } \\
\text { partnership }\end{array}$ \\
\hline
\end{tabular}




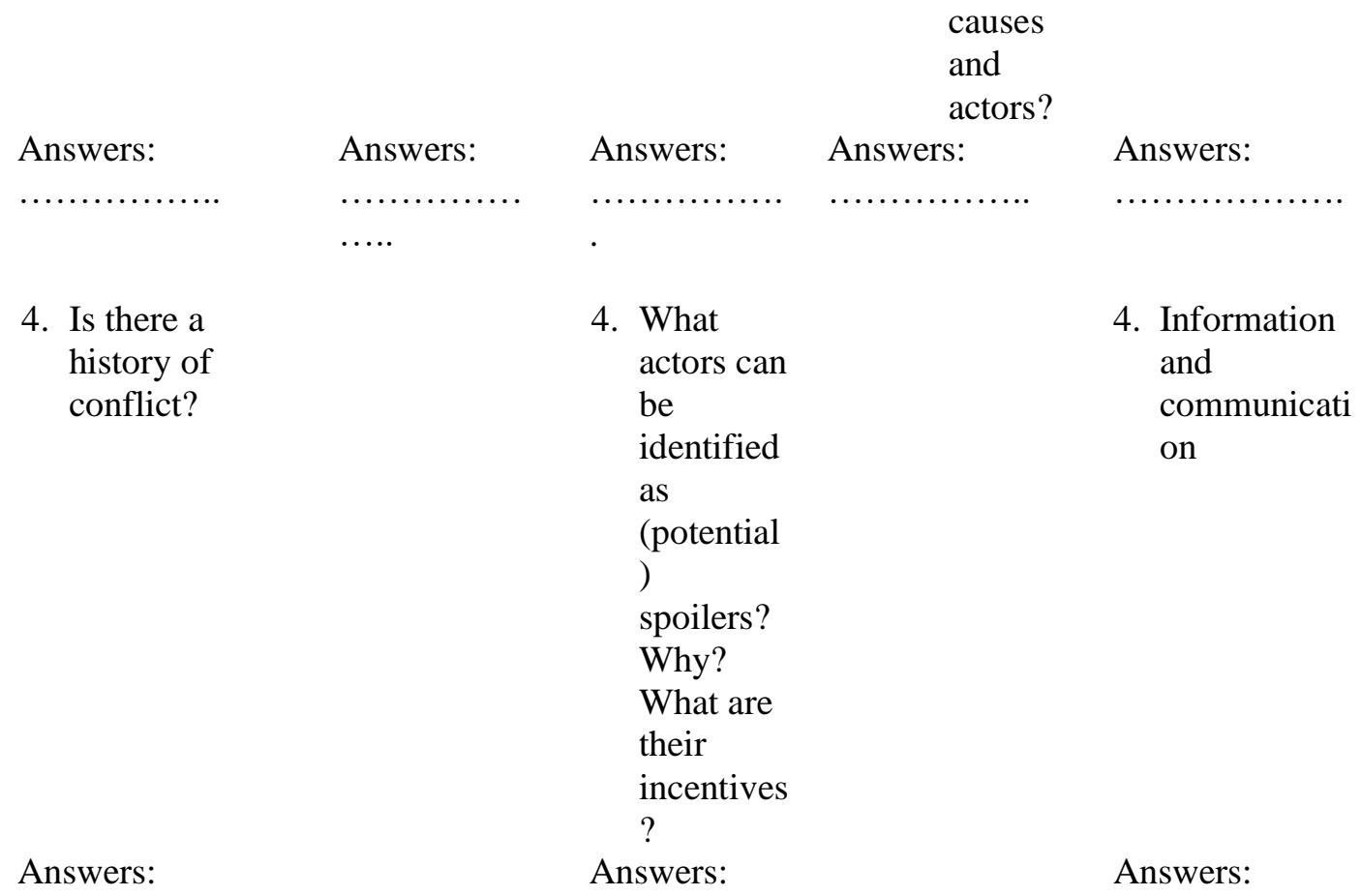

\section{Social} inclusion and cohesion

Answers:

6. Empowerme nt and political action

Answers:

\subsection{Conflict Potentials Profile}

What is happened after determining integrative conflict mapping? The simple answer is to map the conflict potentials. Yes, it provides that this instrument make the mapping running on the track and data base gained. Through implementation of this integrative mapping, we could find important data. It is urgent to see the table 1 below. 
Table 1. Conflict Potentials in 5 Regencies at South Sulawesi Province, Indonesia

(May 2013 to May 2016)

\begin{tabular}{|c|c|c|c|c|c|c|c|}
\hline \multirow{2}{*}{ Num. } & \multirow{2}{*}{ Conflict Issues } & \multicolumn{5}{|c|}{ Regencies } & \multirow{2}{*}{ Total } \\
\hline & & Gowa & Takalar & Bantaeng & Sinjai & Selayar & \\
\hline 1 & $\begin{array}{l}\text { Natural and environmental } \\
\text { resources. }\end{array}$ & 11 & 10 & 7 & 15 & 6 & 49 \\
\hline 2 & Economic resources. & 14 & 1 & 2 & 3 & 5 & 25 \\
\hline 3 & Ethnic and religion & 7 & 3 & - & 3 & 2 & 15 \\
\hline 4 & $\begin{array}{l}\text { Communal Conflict among } \\
\text { community }\end{array}$ & - & - & - & 1 & 2 & 3 \\
\hline 5 & Politics and territory & 8 & 1 & 1 & 3 & 2 & 15 \\
\hline 6 & Drugs business & 5 & - & 5 & - & - & 10 \\
\hline \multirow[t]{3}{*}{7} & Household/Family & 5 & - & - & - & - & 5 \\
\hline & Sub Total & 50 & 15 & 15 & 25 & 17 & \\
\hline & Total & \multicolumn{6}{|c|}{122} \\
\hline
\end{tabular}

The table above shows that natural and environmental resources is the main conflict potentials, it is 49 potentials along May, 2013 to May, 2016. The next major potential is the economic resources issue, 25 potentials. Then, ethnic and religion issue are 15 , politics and territory are 15 . Drugs business are 10 potentials and the last household/family issue are 5 .

Further description, major conflict issue in Gowa regency is economics resources. It is followed by natural and environmental issue, politics and territory, ethnic and religion, drugs business, household/family, and no communal conflict among community. The total of conflict potentials is 50 . Takalar regency has 15 conflicts potentials issues, Bantaeng, either. Sinjai has 25 potentials, and Selayar has 17.

\subsection{Social Capital Potentials and Obstacles}

The implementation of the integrative instrument that has been proposed above, the study found the conflict potentials and conflict category based on issue as descripting at table 1 above. More ever, this integrative instrument find the social capital potentials and obstacles to find conflict solution in the area of study. For clear point, see the table below:

Table 2. Social Capital Potentials and Obstacles in Finding Conflict Solution

\begin{tabular}{ll}
\hline \multicolumn{1}{c}{ Potentials } & \multicolumn{1}{c}{ Obstacles } \\
\hline $\begin{array}{ll}\text { 1. Informal regular meeting of governmental } \\
\text { leaders and social group leader in each }\end{array}$ & 1. Trust degradation to the local \\
regency, such as, coffee morning. & 2. Social cohesion degradation. \\
$\begin{array}{ll}\text { 2. The care and sympathy of traditional or } & \text { 3. Moral and social norms } \\
\text { informal leader toward conflict. } & \text { degradation. }\end{array}$ \\
$\begin{array}{ll}\text { 3. The economic empowerment for society. } & \text { 4he moral degradation of family. }\end{array}$
\end{tabular}


4. The participation existence of social group, civil society organization toward peace care.

5. There is coordination between governmental security, police, military and informal social leader.

6. The existence of cultural and religion values.

7. Sectoral Police Department identified social informal leader in the local area.

8. The communication between social leaders, 10 governmental leader, social group leaders toward peace keeping and building still exist.
5. Education and politic etic achievement still low

6. Religion dis-function impacts to the rising of social suspicion.

7. The cultural values tend to degrade.

8. The weakness of low enforcement.

9. The weakness of governmental coordination toward conflict prevention.

10. The function of social institution goes to weakening.

Data at the table above determine that there are social capital potentials can be organized to prevent conflict potentials, even, to manage and finding conflict resolution. This is to ease conflict potentials based on the local community wisdom. On the other hand, it found some obstacles of social capital to find conflict resolution.

\section{DISCUSSION}

\subsection{Strategic Instrument}

Based on criteria of Social Ministry of Indonesia in collaboration with Titian Perdamaian, the intensity of conflict potentials in Gowa regency include in 'highest' potentials because it more than 20 potentials. Sinjai regency includes highest potential too. Whereas, Takalar, Bantaeng and Selayar regencies include in middle level potentials because the potentials are between 5 to 20 potentials. This proofs that the integrative instrument enable to the whole stakeholders provide strategic planning towards conflict potentials. Trough the instrument government can design a blue print of conflict according to the character of each area of regencies, even, can be provided for the lower governmental level, such sub-district or village level. Therefore, this ICPM as instrument is very strategic instrument indeed.

\subsection{Strategic Empowerment}

The providing of conflict profile through the instrument of integrative conflict potentials mapping enables the conflict stakeholders, include government, civil society, local community leader, donor, private sector, and the whole elements involved to design the effective and efficient strategy to prevent, manage and finding conflict resolution base on the local potentials. It is named strategic empowerment. 
The strategic empowerment does not only handle by one stakeholder, but it must involve the whole stakeholders because conflict experience proved that it has impacted the whole sectors of human life, more ever, spreading out of the conflict area. The conflict can spread to the whole issues, either, such economic, politics and territory, natural resources, religion, governmental institution, military, ethnicity, family, etc. Thus, it reasons to enable the whole elements of social life to involve carrying conflict potentials.

Related to the time and range of conflict, the elements of social life can arrange the strategic empowerment according the priority scale. It may be short, middle and long term empowerment, more ever, sustainable empowerment, include participative empowerment. Whatever, there must be a strategic empowerment to care conflict potentials, of course, after providing conflict profile through ICPM.

\subsection{A Discourse of Conflict Responsive of Area}

The Ministry of Rural and Underdeveloped Area Development of Indonesia had taken a memorandum of understanding with Hasanuddin University (Unhas) to map the needs of involved people in conflict area in order to build a conflict responsive area. Hence, the team of Unhas had proposed a concept of conflict responsive area. At the time, at Friday, September 11, 2016, the team handled a focused group discussion (FGD) to define out the concept. This FGD was attended by Darmawan Salman (a professor), A.M. Imran Oemar (professor), H.M. Darwis (doctor), Suparman Abdullah (doctor), Hasrat Arief Saleh (doctor), and Syamsuddin Simmau (master), they were the member of team. In this occasion, the FGD had been success to form the concept of conflict responsive area.

Based on the FGD, the conflict responsive are is the area where the whole people there, have high awareness to respond conflict in three conditions; pre-conflict, being conflict, and post conflict. Each condition has indictors. For clear point of view, look at the following matrix.

\section{Matrix of Conflict Responsive Area and Indicators}

\begin{tabular}{ll}
\hline \multicolumn{1}{c}{ Conditions } & \multicolumn{1}{c}{ Indicators } \\
\hline Pre-Conflict & The early conflict detection: \\
& 1. Conflict discourse \\
& 2. Conflict potentials \\
& 3. Events tended to conflict potentials \\
Being Conflict & The effectiveness to stop conflict: \\
& 1. The ability to minimize conflict escalation \\
& 2. The ability to stop conflict \\
Post Conflict & The effectiveness of conflict recovery:
\end{tabular}


1. Psychologically

2. Economically

3. Socially

4. Culturally

5. Infrastructure

A main important recommendation of the FGD is to provide conflict profile before doing intervention for conflict management or conflict resolution. In this case, there must be a need assessment towards conflict actors and conflict victims, and even more, stakeholders. Here is the urgency of the integrative instrument of conflict potentials mapping as provided. Therefore, the integrative instrument can be developed as the need of conflict profile. For instance, look at the following matrix:

\section{Matrix of Conflict Profile, Social Capital, and Needs of Conflict Solution To Develop Responsive Conflict Area}

\begin{tabular}{|c|c|c|c|c|c|c|c|}
\hline \multicolumn{4}{|c|}{ Conflict Profile } & \multirow{2}{*}{$\begin{array}{c}\text { Social } \\
\text { Capital }\end{array}$} & \multirow{2}{*}{\multicolumn{3}{|c|}{ Needs of Conflict Solution }} \\
\hline \multirow{2}{*}{$\begin{array}{c}\text { Profile } \\
\text { of } \\
\text { Conflict }\end{array}$} & Conflict & Conflict & Conflict & & & & \\
\hline & & & & & $\begin{array}{c}\text { Pre- } \\
\text { conflict }\end{array}$ & $\begin{array}{c}\text { Being } \\
\text { Conflict }\end{array}$ & $\begin{array}{c}\text { Post } \\
\text { Conflict }\end{array}$ \\
\hline
\end{tabular}

The matrix above proves that ICPM is enable researchers to develop a complete model according their need, area of conflict, and socio-cultural condition of society where study handled. It determines that the ICPM is really a strategic instrument towards conflict prevent, management and finding conflict resolution.

\section{CONCLUTION}

The ICPM is a strategic instrument for conflict prevent, management and conflict resolution. It is important to emphasize that ICPM can provide conflict profile, social capital potentials, needs of conflict solution. The implementation of this model can provide a design of conflict responsive area base on local people wisdom. It depends on the area of conflict because conflict itself cannot be prevent, managed and solved in one way generally. Conflict must be handled based on conflict profile, social capital as manifestation of locality assets, and the needs of conflict solution. 


\section{REFERENCES}

Abdullah, Suparman, 2016. Social Capital Approach in Social Interaction and Integration, (Slide Presentations). Social Department of Provincial Office of South Sulawesi.

Hasbullah, Jousairi. 2006. Social Capital Towards the Excellence of Indonesian Culture. Jakarta: MRUnited Press.

Ife,Jim \& Tesoriero, Frank. 2008. Community Development: Community Based Alternatives in on Age of Globalization (Translated into Indonesian Language by Sastrawan Manullang et.al.). Yogyakarta: Pustaka Pelajar.

Social Ministry of Indonesia General Directorate of Protection and Social Insurance, Directorate of Social Protection and Victims of Social Riots in Collaboration with Titian Perdamaian). (2013). A Guide to Social Conflict Mapping of Potential Conflict Area). Jakarta: Social Ministry of Indonesia.

Lin, Nan. 2004. Structure Analysis in the Social Science Social Capital a Theory of Social Structure and Action. Cambridge: Cambridge University Press.

Pruitt, Dean G and Jeffrey Z. Rubin. (2009). Social Conflict Escalation, Stalemate, and Settlement. (Translated into Indonesian Language by Helly P. Soetjipto and Sri Mulyantini Soetjipto). Yogyakarta: Pustaka Pelajar.

Ritzer, George, Douglas J. Goodman.(2004). Modern Theory of Sociology (Sixth Edition, Translated into Indonesian Language by Alimandan). Jakarta: Kencana Prenada Media Group

Susan, Novri. (2010). Introduction to Conflict Sociology and Contemporary Conflict Issues). Jakarta: Kencana Prenada Media Group.

The Conflict Sensitivity Consortium (CSC). 2012. How to Guide to Conflict Sensitivity. UK: UKaidThe Conflict Sensitivity Consortium.

www.snpk.indonesia.com. accessed on August 2015. 